AperTO - Archivio Istituzionale Open Access dell'Università di Torino

Producer and farm characteristics, type of product, location: Determinants of on-farm and offfarm direct sales by farmers

This is a pre print version of the following article:

Original Citation:

Availability:

This version is available http://hdl.handle.net/2318/1658902

since 2018-10-30T11:27:34Z

Published version:

DOI:10.1002/agr.21548

Terms of use:

Open Access

Anyone can freely access the full text of works made available as "Open Access". Works made available under a Creative Commons license can be used according to the terms and conditions of said license. Use of all other works requires consent of the right holder (author or publisher) if not exempted from copyright protection by the applicable law. 


\title{
Producer and farm characteristics, type of product, location: determinants of on-farm and off-farm direct sales by farmers
}

\author{
Alessandro Corsi, Silvia Novelli, Giacomo Pettenati
}

\section{INTRODUCTION}

Direct sales are a widespread and important typology of the so-called Alternative Food Networks (AFN). The concept of AFN is mainly used in the sociological literature (e.g., Marsden et al., 2000; Winter, 2003; Whatmore et al., 2003). AFNs have been described in terms of many different properties and qualities, such as: embeddedness in regional and local food-culture, quality of food production, sustainability of the food supply chain, democracy of social and economic relations, added value for the rural territory and farmers, and so on (e.g., Feenstra, 1997; Ilbery et al., 2004). In the geographical literature AFNs (such as direct sales) have been considered as an example of the new rural development patterns at a regional scale, within the theories of "alternative geographies of food" (Murdoch et al., 2000; Sonnino and Marsden, 2006; Wiskerke, 2009), or "new geographies of food" (Gatrell et al., 2011). In the economic literature, much research has been devoted to analyse the motivations and the behavioral characteristics of consumers who purchase local foods or at farmers' markets. The corresponding issue on the supply side is farmers' choice of the relevant marketing channel. The economics literature dealing with farmers' choice to sell directly their products is nevertheless not huge. On-farm sales are sometimes included among multifunctional activities (Jongeneel et al., 2008); some research investigates the determinants of the weight of direct sales (Timmons and Wang, 2010) or the number of farms directly selling their produce (Lyson and Gutpill, 2004) using aggregate data. Some related literature concerns the choice of coffee producers to sell at the farmgate or to travel to the market (Fafchamps and Vargas Hill, 2005) or the choice of the sale mechanism, like forward contracts vs. cash sale (Fletcher and Terza, 1986; Fu et al., 1988; McLeay and Zwart, 1998). Verhaegen and Van Huylenbroeck (2001) assess the economic profitability for 
some case studies of direct sales (off the farm), and Brown and Miller (2008) review the studies on the impact of Community Supported Agriculture on farmers' incomes. Corsi et al. (2009) model the determinants of the choice of the marketing chain of organic producers distinguishing between conventional and alternative chains, the latter including direct sales. Aguglia et al. (2009) and Bonanno et al. (2014), both on the basis of Italian FADN data, analyse the determinants of the choice of direct selling and of the share of turnover due to sales in short chains, respectively. Adanacioglu (2016) examines the factors affecting the direct marketing of cherry producers in Turkey.

None of these studies analyses the difference between on-farm and off-farm direct sales. Direct sales can indeed take two basic forms: consumers going to buy agricultural products at the farm (onfarm sales, pick up at the farm), and farmers selling their products in urban areas (off-farm sales: farmers' markets, community supported agriculture drop-off, and buying groups). We argue that this distinction is important, for two reasons. First, the determinants of these choices are potentially different. Second, since it is often argued that short food chains are more environmental-friendly, one should consider that the environmental implications can be quite different: for instance many individual consumers moving to the farm presumably pollute more than a single farmer bringing the same quantity of product to town.

The aim of this paper is to understand the determinants of farmers' choice to undertake such practices. The empirical analysis concerns an Italian Region, Piedmont. Firstly, the territorial distribution of direct sales practices (on-farm or off-farm) is analysed, so to have a geographical picture of the distribution of these practices. Secondly, we analyse the determinants of the choice to sell directly to consumers. We depart from previous literature in using individual farm data to model the choice of selling directly, and in distinguishing between on-farm and off-farm direct sales, since in principle they entail different determining factors. 


\section{THEORETICAL AND METHODOLOGICAL APPROACH}

Farmers' choice to sell directly their products rather than using the conventional marketing chains can be modelled as a comparison between the utility they get from the alternative vs. the conventional chain. Utility for each choice stems from the income each chain provides, and possibly from non-pecuniary benefits deriving from the same chain. Direct sales can be a strategic choice for the farmer, which implies adapting the setting of the farm to this choice. For instance, direct sales of vegetables often require producing several different products to provide an adequate choice to consumers, while industrial farming is typically oriented towards specialisation. However, direct sales can also be a choice only concerning the marketing channel, based on the comparison between revenues and costs of the distribution of the product. In the most general terms, call $\mathrm{y}_{\mathrm{j}}{ }^{*}$ the vector of products resulting from an optimal configuration only using the conventional chain, and $\mathrm{y}_{\mathrm{i}}{ }^{*}$ the corresponding vector from an optimal configuration using, even partially, direct sales. Then the difference between profits with direct sales and with the conventional chain $\left(D_{p}\right)$ is therefore:

$$
D_{p}=\left(\sum_{i} p_{y i}^{*} y_{i}-\sum_{i} V C_{i}-F C_{i}\right)-\left(\sum_{j} p_{y j}^{*} y_{j}-\sum_{j} V C_{j}-F C_{j}\right)
$$

where $\mathrm{p}_{\mathrm{yi}}$ are the prices of $\mathrm{y}_{\mathrm{i}}{ }^{*}$, and $\mathrm{VC}_{\mathrm{i}}$ and $\mathrm{FC}_{\mathrm{i}}$ are the variable and fixed costs, respectively, associated with (possibly partial) choice of direct sales; $\mathrm{p}_{\mathrm{yj}}$ are the prices of $\mathrm{y}_{\mathrm{j}}{ }^{*}$, and $\mathrm{VC}_{\mathrm{j}}$ and $\mathrm{FC}_{\mathrm{j}}$ are the variable and fixed costs, respectively, associated with the conventional chain only. Variable and fixed costs for both channels comprise costs of the distribution channel, if any.

Usually, direct sales give higher revenues, since selling prices are higher. The price premium may depend on the product characteristics, since some lend themselves to direct sales more than others do. It also depends on the place where they are produced, so that, e.g., products from the mountains or from specific areas can have a higher appreciation by consumers buying directly than the ones from other areas. However, direct sales may also imply higher costs, both variable and fixed, since the distribution costs are borne by the farmers. For instance, for selling on the farm, a place for selling is needed, and labour must be devoted to this activity. When practicing off-farm direct sales, 
farmers bear transportation costs, administrative and other out-of-pocket costs for permits to sell and, obviously, the labour cost for time devoted to this activity ${ }^{1}$.

In empirical terms, monetary revenues and costs can therefore be modelled as a function of the type of product $(\mathrm{T})$; of farm characteristics $(\mathrm{F})$; of production and marketing skills of operators, as represented by personal characteristics $(\mathrm{O})$; of farm location $(\mathrm{L})$, that affects transportation costs for off-farm sales, and demand (and, hence, prices) for both on- and off-farm sales; and of unknown farm and personal characteristics, that can be modelled as a random component $\varepsilon$. Hence, the difference in profits between the two chains can be written as:

$$
D_{p}=D_{p}(T, F, O, L, \varepsilon)
$$

On the other hand, direct sales may have non-pecuniary benefits, because farmers may decide to adopt it for ideological reasons, or they may like having personal contacts with consumers, the possibility to explain the virtues of one's products, or the like. They can be assumed to be a function, at least partially, of operators' personal characteristics $(\mathrm{O})$, like age, education, gender, etc., and of unobservable idiosyncratic personal characteristics represented by a random component $\eta$, so that the difference in utility due to non-monetary benefits is:

$$
D_{n m u}=D_{n m u}(O, \eta)
$$

with $n m u$ indicating non-monetary utility.

We assume that the utility from monetary and non-monetary benefits is additive. Hence, the choice of the marketing chain is made based on the comparison between the overall utility provided by each alternative. In empirical terms, the choice of direct sales can be modelled as:

$$
\begin{aligned}
& S=1 \text { if } D_{U}=U_{d}-U_{c}>0 \\
& S=1 \text { if } U\left[D_{p}(T, F, O, L, \varepsilon)\right]+D_{n т и}(O, \eta)>0
\end{aligned}
$$

\footnotetext{
${ }^{1}$ Herdesty and Leff (2009) analyze the distribution costs of different marketing channels in some case studies.
} 
where $\mathrm{S}$ is a dummy indicator of the choice to sell directly; $\mathrm{D}_{U}$ is the difference between the utility from the direct sales and the utility of the conventional chain; $U_{d}$ is the utility stemming from practising direct sales and $U_{c}$ is the utility from any alternative choice; $U\left[D_{p}\right]$ and $D_{n m u}$ are monetary and non-monetary net benefits from the choice of direct sales. Attaching random components to the variables, and assuming a linear form, the model is:

$$
\begin{aligned}
& \operatorname{Prob}(S=1)=\operatorname{Prob}\left[D_{U}(T, F, O, L)>0\right]=\operatorname{Prob}\left[\alpha_{0}+\alpha_{1} \mathrm{O}+\alpha_{2} F+\alpha_{3} L+\alpha_{4} T+\zeta>0\right]= \\
& =\Phi_{\zeta}\left(\alpha_{0}+\alpha_{1} \mathrm{O}+\alpha_{2} F+\alpha_{3} L+\alpha_{4} T\right)
\end{aligned}
$$

where $\Phi$ is the normal cdf for $\zeta(=\varepsilon+\eta)$, and $\alpha_{0}, \alpha_{1}, \alpha_{2}, \alpha_{3}$, and $\alpha_{4}$ are parameter vectors to be estimated. The model has been estimated as a probit by maximum likelihood techniques.

\section{DATA}

The analysis is based on data collected through the 2010 Agricultural Census for Piedmont. Piedmont is located in the North-West of Italy, near the French border. It has a relatively high average income, and was a traditionally industrial region, but with a strong agricultural sector, both producing quality products (in particular, wine) and commodities (cereals, dairy). The access to the Census data using the regional data warehouse "CensimentoAGile" allowed the analysis of Census individual farm records of the whole Region.

In 2010, the number of agricultural holdings in Piedmont was 67,148. As a first step, individual farms and group holdings (group of natural persons) were selected $\left(66,459\right.$ holdings) ${ }^{2}$. This selection was made in order to focus on family farms and to exclude from the analysis stock companies, public administrations and cooperatives. Likewise, to exclude hobby farming and self-consumption farms, farms with gross revenues from sales equal to zero were dropped. In the end, 58,304 farms were selected for the analysis.

\footnotetext{
2 The selected holdings were recorded in the agricultural census with the following legal status: "Azienda individuale", "Società semplice" or "Altra società di persone (S.n.c., S.a.s., ecc)".
} 
For each farm and for all types of farm products (vegetable, animal, processed and forest products), the regional database provides the percentage of sales that are marketed through the different marketing channels, i.e. direct on-farm, direct off-farm, manufacturing firms, commercial companies, other farms and producers' cooperatives. The attention was focused on direct marketing channels and on the relevant group of products: cereals (rice inclusive), vegetables, fruits, grapes, milk, dairy products, wine and other processed agricultural products (vegetable and animal). For both on-farm and off-farm direct marketing, a dummy variable equal to 1 for the farms with a positive share of direct sales for one or more products ( 0 for farms not involved in direct marketing) was created $^{3}$.

The explanatory variables for the choice to sell directly to consumers were mostly drawn from the Agricultural Census.

The personal characteristics of the farm operators may affect the choice to sell directly both because of particular skills required to use this channel and because of personal preferences. Younger farmers are usually expected to be more inclined to direct sales, generally being more open to social interactions and having a longer time horizon for the investments - in monetary and human capital needed for the alternative channel. For similar reasons, education is expected to affect positively the choice of direct sales. The personal characteristics included among the explanatory variables are age, years of education undergone 4 , secondary-school diploma or university degree in agriculture, attendance to professional courses in the last twelve months, gender (for which there were no a priori expectations).

\footnotetext{
${ }^{3}$ The Census data concern the share of each group of products marketed through the different channels but, unfortunately, it is not possible to calculate the share of total farm sales marketed through the different channels when a farm produces different products. Weighting the shares with the Standard Output (SO) of the single products is not feasible, unless many different assumptions are made, because the groups do not correspond to the SO aggregations, and because the shares are indicated also for processed products (e.g., wine, cheese) for which there exists no SO different from the raw product. These are the reasons why we use a dichotomous variable rather than the overall share of products marketed directly. The possibility to estimate the percentage of revenue from direct sales with appropriate assumptions and estimations is left for further research.

${ }^{4}$ Since the Census only records the education level, years of education were calculated as the number of years needed to reach the relevant level under the hypothesis of regular studies.
} 
The structural characteristics of the farms arguably matter for the choice of the alternative marketing channel. There is a widespread common opinion among agricultural extension bodies that direct sales are fit for small farms rather than for large ones ${ }^{5}$. The scientific literature seems to confirm the correlation between small-scale farming and the propensity to sell directly, both in terms of share of farms involved in direct selling (Aguglia et al., 2009; Feenstra et al., 2003; Lev and Gwin, 2010; Lov and Vogel, 2011) and percentage of direct sales, reported as higher in small farms than in large farms (Martinez et al., 2010). For some authors, direct marketing has the potential to increase small farm income, diversifying or adding value to the farm product, and it often represents one of the few options for small entrepreneurs to maintain or enhance their market niche in a community (Cheng et al., 2011; Feenstra et al., 2003; Morgan and Alipoe, 2001). However, it should be noted that showing that the majority of farms practicing direct sales are small does not imply that small farms are fit for it, because it might simply reflect the high share of small farms on the total. It is rather the share of farms practicing direct shares among the small farms and among the big ones that is relevant.

We used the Standard Output ${ }^{6}(\mathrm{SO})$ as a measure of the economic size of the farm. In addition, the possibility of selling directly arguably differs with the type of products. For instance, some products need processing in dedicated plants before they are consumed (e.g., animals need slaughtering, cereals need milling, etc.) and cannot be sold on the farm unless such processing is also made on the farm. Since considering the individual products was impossible, also due to the possibility that many farms produce several different products, we used as an indicator the Type of Farming (TF) calculated with the methodology of the FADN 7.

Other characteristics linked to the quality of products may increase the benefits of direct sales. Organic farming is often associated with direct sales, since for many consumers the direct relationship

\footnotetext{
5 Some examples among the others can be seen in the following extension webpages: www.agric.wa.gov.au; http://edis.ifas.ufl.edu; http://extension.colostate.edu; http://articles.extension.org. All were accessed 17 Jan 2017.

${ }^{6}$ The Standard Output is calculated in the Farm Accounting Data Network (FADN) of the European Union as standard value of production, determined for the various crop and livestock characteristics within each region.

${ }^{7}$ The Farm Accounting Data Network defines a farm as specialised in a TF if the Standard Output (SO) for the particular production covers more than $2 / 3$ of total SO.
} 
with the farmer involves, along with the idea of grassroots, an idea of "natural" that is a characteristic image of organic products. Collective brands like protected designation of origin (PDO) and protected geographical indication (PGI) are also associated with quality, though the association with direct sales is a priori less clear. All these characteristics are represented by dummy variables.

Other farm activities (agro-tourism, supply of on-farm recreational activities) involve relationship with customers that are expected to be conducive to an increase in the likelihood of direct sales. This is quite obvious in the case of agro-tourism, especially when it includes a restaurant, since it gives the possibility to sell the products directly to the customers; but also recreational activities create a knowledge of the farm that facilitates the establishment of a commercial relationship. Notice that a priori one would expect this to be true for on-farm direct sales, not necessarily for off-farm direct sales.

Farm location may affect the choice of practising direct sales in different ways. On the supply side, small farms with family labour exceeding farming requirements may or may not find alternative job opportunities depending on the area where the farm is located; in the case when few off-farm labour opportunities are available, direct sales may represent an alternative strategy of employing family labour. Second, farm location is relevant for the marketing costs associated with off-farm direct sales, in terms of transportation costs to the location of sale. Third, mainly with reference to on-farm direct sales, the number of potential customers and the distance they are coming from may be an important determinant of the demand for the farm products. To keep into account these points we used three variables. One is altimetry (plains, hills, mountains), since mountainous and hilly areas generally provide less job opportunities, but on the other hand their products may have more appeal to consumers. The second is the number of main commercial cities at half-hour driving distance from the farm ${ }^{8}$ that tried to capture the transport costs for farmers deciding to sell off the farm and the

\footnotetext{
${ }^{8}$ The reference is to the 37 cities and towns, which Regione Piemonte identifies as "commercial poles" and to the homologous towns in the neighbouring regions (Liguria, Valle d'Aosta, Lombardy and Emilia-Romagna). This variable was created with the Microsoft MapPoint software.
} 
opportunities to sell to urban consumers. The third is the population living within a 45 minutes car driving distance from the farm, a variable intended to quantify the basin of potential consumers that could easily reach the farm to buy its products on site with low transportation costs ${ }^{9}$.

\section{Results}

\subsection{Shares of farms selling directly}

Table 1 shows the percentage of farms that market directly at least one product among those considered in the analysis. Overall, direct sales appears to be a minor marketing channel. Only $14.0 \%$ of all farms sell directly on-farm, and $8.1 \%$ off-farm (the two channels are combined in 2,014 farms, i.e., 3.5\%). The shares strongly differ with the type of farming (TF). On-farm direct sales are higher for unspecialized farms (mixed cropping, mixed livestock, field crops and grazing livestock combined, various crops and livestock combined; in short, Mixed). Unspecialized farms engaged in direct on-farm marketing are $24.4 \%$. The specialist viticulture exhibits almost the same weight (24.3\%), while other permanent crops (15.3\%), specialist sheep and goats (14.1\%), dairying (13.5\%) and horticulture (13.2\%) are at a lower level. The lowest percentage is - not surprisingly - for fieldcrops and specialist cattle (beef).

\section{Table 1 about here}

As to off-farm direct sales, horticulture has the highest percentage $(16.1 \%)$, while for mixed farming and viticulture the percentages are $14.7 \%$ and $13.6 \%$, respectively. Again, fieldcrops and cattle have the lowest percentages.

\footnotetext{
${ }^{9}$ The data on population are from Istat (2016) and refer to the population living in Piedmontese municipalities in 2015. The variable of the population living within 45 minutes driving distance from the municipality of the farm was created with Microsoft Map Point 2011 and QGIS 2.8.3.
} 


\subsection{Geographical distribution of the farms selling directly}

A second important feature of direct sales is the territorial distribution of farms engaged in this marketing channel. This aspect is relevant for both on-farm and for off-farm direct sales. However, the reasons are different. With on-farm sales, it is the consumer that moves to the farm to buy. The number of consumers at a close distance from the farm might be relevant, since not a large share of them does go to the farms to buy, and a larger population implies more potential consumers. For offfarm sales, it is the ease for farmers to find urban markets that is more relevant, so that the vicinity to urban centres where to sell one's products is expected to be an important determinant. Moreover, other non-pecuniary factors may be at work. These include, for instance, the relationship that dwellers may have with the surrounding territory, including the cultural heritage, the appreciation of local food, and the network of social relationships between the city and the countryside. The strict relationship between practices of Alternative Food Networks (such as direct sales) and the new rural development patterns at a regional scale brought scholars to talk about "alternative geographies of food" (Murdoch et al., 2000), or “new geographies of food” (Gatrell et al. 2011).

As Figure 1 in the Appendix shows at the municipal scale, the farms engaged in off-farm direct sales are mostly concentrated in specific clusters, such as the hilly wine-growing areas of Langhe and Monferrato, the hilly belt surrounding Torino (the main town of the region), and some low Alpine valleys (again in the province of Torino). There seems to be an attraction of the urban centre of Torino behind the two latter areas, whereas Langhe and Monferrato are rather agro-tourism areas. The picture is different concerning farms selling directly on-farm: there is again a widespread presence in the Langhe and Monferrato areas, which can be linked to agro-tourism, and in the hills around Torino, that can be easily reached from the city; but some concentrations can also be found in different areas. The ratio of the farms practising on-farm direct sales to the total number of farms in each municipality (Figure 2 in the Appendix) is much more homogeneously distributed across Piedmont, with higher values in the mountains (both Alps and Apennines) and in the hilly areas, possibly due to the lower 
total number of farms. Off-farm sales, on the other hand, still appears as quite concentrated in the hills and mountains surrounding the metropolitan area of Torino. Overall, the picture of the territorial distribution of farms engaged in direct sales is not much clear. Along with the influence of the metropolitan centre, other factors seem at work. Hence, a quantitative analysis of the factors influencing farmers' choice to sell directly was performed, according to the theoretical approach illustrated above.

\subsection{Determinants of the choice of direct sales}

Table 2 shows the descriptive statistics of the variables included in the probit model.

\section{Table 2 about here}

As noted above, a priori considerations and the data by TF suggest that different products lend themselves more or less to direct sales. However, there are two different ways in which this can affect the likelihood of direct sales. One possibility is that the farms belonging to a particular TF are more or less likely to practise direct sales, but that the other variables have the same impact on the choice. A different possibility is that the effects of the other explanatory variables are different depending on the particular TF. The first approach can be modelled entering TFs as dummy explanatory variables and running an estimate over the whole sample (dummy model). The second one is allowing the explanatory variables to differ according to the particular TF. This can be done by running the estimates separately for the farms belonging to each TF (split model). Likelihood tests of the constraint that the parameters of the separate estimates are equal to the general one can suggest the most appropriate model.

Table 3 shows the results of the probit "dummy models" for both on-farm and off-farm direct sales, as well as the marginal effects, which indicate the change in probability in the outcome due to 
a unit change of the explanatory variables. As usual, marginal effects are calculated at the mean values of the variables, or at their median, when they are dummies.

Starting with the determinants of on-farm direct sales, operator's characteristics significantly affect the probability of practising on-farm direct sales. Younger operators are slightly more willing to undertake this alternative marketing channel, as each additional year decreases the probability by $0.1 \%$. Males are $0.8 \%$ more likely to do it, and every additional schooling year adds $0.3 \%$ to the probability. The operator having attended an agricultural school or university increases the probability by $4.1 \%$, and having attended professional training courses in the last year by $4.9 \%$. In general, hence, human capital seems to favour this choice, but the impact is rather weak.

Contrary to other studies (Aubert, 2015; Cheng, 2011; Monson et al., 2008), the effect of the economic size is positive but, as measured by the Standard Output (SO), though statistically significant, it is almost negligible in economic terms. A rise in SO by 10,000 euro only increases the probability by $0.01 \%$, which means that to all practical purpose small and large farms are not different.

The effect of diversification activities undertaken by the farm is much stronger. If the farm has some agro-tourism, or recreational activity, the likelihood of selling directly on the farm is $25.4 \%$ and $10.5 \%$ higher, respectively. This is an expected result, as receiving guests on the farm gives opportunities to sell one's products. Organic farming too is relevant, as it increases the probability by almost $6 \%$.

\section{Table 3 about here}

As to the Type of Farming, all specialised TFs have a lower probability to sell directly on the farm relative to the Mixed TFs, taken as reference. The difference ranges between $-13 \%$ for Fieldcrops (mainly cereals) to $-6.6 \%$ for Horticulture, a TF that was expected to have a greater share 
of farms selling directly. Only for Viticulture the difference with mixed farming is not significant, which can be easily explained by the importance of wine tourism in Piedmont. It is apparent that mixed type of farming and viticulture lend themselves to on-farm direct sales more than specialised TFs.

Concerning the location, altimetry is important. Relative to plains, farms located in the mountains are $17.8 \%$ more likely to sell their products on the farm, and farms in hills $8.7 \%$. The number of "pole" municipalities that can be reached in a half hour drive is arguably more relevant for off-farm direct sales, but it is statistically significant and its exclusion was rejected by a likelihood ratio test. Its effect is negative, but actually almost negligible (the marginal effect is $-0.2 \%$ for each additional pole). Finally, the population that can reach the farm within a 45 minutes car drive was taken as an indicator of the potential demand for agricultural products purchased on the farm, as the distance affects the relevant cost for consumers. The effect of this variable is significant and strong, as shown by the marginal effect: 10,000 more "potential consumers" increase the probability by $27 \%$. To sum up, the most important determinants for on-farm direct sales according to this model are the farm location in mountain or hilly areas, the connection with other diversification activities (agrotourism and recreational activities), and the vicinity to many potential consumers, but organic farming also plays a role, while personal characteristics (younger and more skilled and educated operators) and farm size, though significant, are of minor importance.

The results concerning off-farm direct sales are largely similar, but with some significant differences. Personal characteristics bear the same signs as for on-farm direct sales, even with weaker effects. The farm being located in mountain or hilly areas significantly increases the likelihood of offfarm direct sales, though in a lower measure relative to on-farm direct sales. The effect of agrotourism is, quite unexpectedly, significant and positive. In general, specialised TFs have a negative and significant effect on off-farm direct sales, relative to mixed TF. Nevertheless, horticulture TF is not significantly different from mixed TF. This is probably because vegetables production usually concerns several products, and follows the seasons, so that different products can be sold directly all- 
year round, as required by consumers. The variable concerning marketing places that can be reached within short driving distance is in this case an indicator of potential transportation costs that farmers deciding to sell directly have to bear. This variable is significant and positive, meaning that more towns where it is possible to sell do increase the probability that the farmers sell directly. Nevertheless, the effect is rather weak (an additional town increases the probability only by $0.4 \%$ ). This suggests that transportation costs, though relevant, are not crucial in this field. It is also interesting to note that the population living within a short distance from the farm has a positive effect on the probability to sell directly off the farm.

As already mentioned, though, there exists the possibility that the effects of the variables differ among Types of Farming. This can be tested estimating a model:

$$
\operatorname{Prob}(\mathrm{S}=1)=\Phi_{\varepsilon}\left(\sum \mathrm{d}_{\mathrm{i}} \mathrm{X}_{\mathrm{i}} \beta_{\mathrm{i}}\right)
$$

where $d_{i}$ represent dummy variables equal to 1 when the farm belongs to TF $i$, else $0, X$ are the explanatory variables other than $\mathrm{TF}$, and $\beta_{\mathrm{i}}$ the relevant parameters to be estimated, separately for each TF. The model has been tested against the dummy model by testing the restriction that all $\beta_{\mathrm{i}}$ are equal. The likelihood ratio tests strongly reject the restrictions. Hence, it should be concluded that the explanatory variables differently affect the probability of direct sales contingent on the particular TF. In practical terms, this means that the choice of the type of farming precedes the choice of selling directly. Accordingly, we estimated separate probit models for each TF. The relevant estimates are presented in Tables 4 and 5.

\section{Tables 4 and 5 about here}


The picture emerging from the results of the "split model" is much more diversified. Not only some of the variables affecting the choice of direct sales are significant for some TFs and not for others, but in some cases significant parameters even bear different signs in different TFs.

Starting with on-farm sales, the only variable that has a significant, strong and positive effect in all TFs is agro-tourism. At the mean values of the variables, a farm with agro-tourist activities is $14 \%$ (for Dairying) to $46 \%$ (Granivores) more likely to engage in direct sales. The connection between agro-tourist activities and on-farm sales is quite obvious, since people eating or lodging on the farm very easily can also buy farm products. By contrast, the presence of recreational activities is not always conducive to direct sales. It has this positive effect on the probability of direct sales especially for Beef $(+56.3 \%)$ and Horticulture $(+46.6 \%)$, but also for Mixed crops $(+21.3 \%)$ and Fieldcrops $(+12.6 \%)$, but not for the other TFs.

Among the characteristics of the products, organic farming has a strong effect for Vineyards (the marginal effect is $+23.1 \%)$ and Horticulture $(+21.2 \%)$, a sizeable one for sheep $(+11.2 \%)$, Mixed crops $(+10.9 \%)$, and Fieldcrops $(+7 \%)$, but no significant effect on the other TFs. PDO-PGI qualification has a positive effect specially for animal productions, Beef (marginal effect of $+4 \%$ ) and Sheep (+20.8\%), probably concerning cheese.

Our results do not support the view that direct sales lend themselves more to small farms, not even for particular TFs. The estimates of the Standard Output variable are only significant for Vineyards, Dairying, and Beef, but in these cases, they are positive, implying that larger farms do sell more directly. However, the marginal effects suggest that the effect is negligible since, e.g., a 100,000 Euro increase in Standard Output is needed to increase only by $3 \%$ the probability of on-farm direct sales for Vineyards, and the results are similar for the other TFs. This outcome is similar to the one by Aguglia et al. (2009), for which the Standard Gross Margin was not significant.

The effects of the operator's characteristics are in general weak. The coefficient of age has a negative sign (suggesting that younger operators are more likely to sell directly) for all TFs except 
Granivores, but is only significant for Mixed crops, Fieldcrops, and Beef, and in all these cases an additional year decreases the probability by just $0.1 \%$. An intriguing result, difficult to explain, is that males are more likely to adopt direct on-farm sales when the TF is Vineyards and Fruits, while the opposite holds for Fieldcrops and Horticulture. However, the impact of gender is rather modest: the largest marginal effect is $6 \%$ for Vineyards. Education always shows a positive effect, though not for all TFs; again, the effect is nevertheless weak, as each additional year of school only adds less than $1 \%$ to the probability of on-farm direct sales. The effect of an education in the agricultural field is again different, significant and negative - but rather weak - for Horticulture, significant and positive for Fieldcrops, Sheep and Viticulture (in the latter the marginal effect is particularly strong, 18.1\%, possibly because viticulture schools might be more market-oriented). Finally, if the operator followed a professional course in the last year he/she is more likely to adopt direct sales, though not significantly so for all TFs; the marginal effect is sizeable for Sheep $(+14.6 \%)$, Mixed crops $(+10.8 \%)$, Fruits $(+7.6 \%)$ and Dairying $(+6.5 \%)$, less for Fieldcrops $(+1.9 \%)$ and Beef $(+0.5 \%)$, and not significant for the other TFs.

Farm location is important, especially for particular TFs. Relative to plains, farm location in the hills or in the mountains increases the likelihood to sell directly on the farm. This holds true for all TFs except Horticulture and (for hills) Granivores. The effect is greater for Mountains than for Hills, and is particularly strong for Mixed crops, Granivores, Vineyards, Dairying, and Fieldcrops. The other variables concerning farm location are the vicinity to commercial poles and the number of inhabitants that can reach the farm within 45 minutes driving distance. The first variable is not significant for several TFs, and exhibits a negative significant sign for some TFs (Fruits, Dairying, Beef), though in practical terms the effect is negligible. This is consistent with the expectations, since vicinity to commercial centres should not influence on-farm direct sales, but rather the possibility to sell off the farm. The negative significant signs can be interpreted as on-farm direct sales being substitutes for off-farm direct sales. The second variable captures the size of the potential customers going to buy on the farm and, indeed, it exhibits significant positive estimates. It is also sizeable, 
since the increase in probability of direct sales for each additional thousand inhabitants within the distance ranges from $2 \%$ to $11.6 \%$. The exceptions (non-significant parameters) concern Fieldcrops, Dairying, Sheep and Granivores, all products usually only bought when processed. This effect depends on the demand side, since it is based on lower costs for consumers to move to the farm to buy food.

Concerning off-farm sales, there is no variable having a significant effect on all TFs. As predictable, agro-tourism has a limited effect on off-farm sales, since it is only significant for Viticulture (the marginal effect is $+8.5 \%)$, Fruits $(+8.2 \%)$, Beef $(+9.5 \%)$, Sheep $(+4.7 \%)$ and Fieldcrops $(2.7 \%)$. It is possible that in these cases agro-tourism creates a reputation for the farm products that can be exploited for off-farm sales. A similar explanation might be valid for recreational activities, whose effect is nevertheless only strongly significant for Fieldcrops.

Organic farming favours off-farm sales, but mostly for vegetal productions. The marginal effect is rather large for Horticulture $(+17.8 \%)$, Viticulture $(+16.8 \%)$, and Mixed crops $(+10.2 \%)$, less for Fieldcrops $(+6 \%)$ and Fruits $(+2.6 \%)$. Among animal productions, only for Sheep organic production affects off-farm sales $(+8.8 \%)$. PDO-PGI qualification in general seems to discourage off-farm direct sales, possibly because other channels allow better prices for these products. Its effect is negative for Mixed crops (-7.4\%), Fruits (-4.1\%), Dairying (-2.5\%), Granivores (-3.4\%); only for Fieldcrops the effect is positive (+4.9).

Also for off-farm direct sales farm economic size has, if any, a positive effect. Standard Output has a significant positive effect for Vineyards, Fruits, Dairying, and Beef, but the marginal effects never exceed 2\% for a 100,000 Euro increase in Standard Output. It is fair to conclude that farm size is not relevant for the choice of off-farm direct sales.

The effects of personal characteristics of the operators are more widespread than for on-farm sales, but in general still rather weak. The age variable is significant and negative (implying that younger operators are more likely to sell directly off the farm) for all TFs except Horticulture, Beef, 
Sheep, but the marginal effects of the significant parameters never exceed $-0.2 \%$ per year. Male operators are less likely to sell off-farm for Fieldcrops (marginal effect equal to -0.7\%) and Horticulture (-8\%), while the opposite holds for Vineyards $(+4.6 \%)$, and the parameters for the remaining TFs are not significant. Education has a significant positive effect for Mixed, Vineyards, Dairying and Granivores, and a significant negative one for Horticulture, but the relevant marginal effects are below $1 \%$ per year. Education in the agricultural field increases the likelihood of off-farm direct sales for Vineyards $(+4.5 \%)$, and decreases it for Horticulture $(-9.6 \%)$ and Dairying $(-3 \%)$. Finally, having attended professional courses makes significantly more likely off-farm direct sales for Mixed crops $(+6.3 \%)$, Vineyards $(+4.9 \%)$, Sheep $(+4.3 \%)$, Fruits $(+3.6 \%)$ and Fieldcrops $(+1.1 \%)$. Summing up, only two TFs suggest specific personal characteristics of the operators engaging in off-farm direct sales: Vineyards, with male operators, more educated especially in the agricultural field and keeping up with professional courses; and Horticulture, with female, young and not so educated operators.

Location in the mountains or in the hills is in general more favourable to off-farm direct sales than the plains. The estimates are significant and positive for both hills and mountains for Mixed crops, Fieldcrops, Vineyards, Dairying, and Beef, and for hills only for Horticulture and Fruits. The effect is in general stronger for the mountains than for the hills: e.g., for Dairying the location in the mountains increases the likelihood of direct off-farm sales by $9.8 \%$, as compared to $3.8 \%$ for hills, and for Vineyards the relevant percentages are $8 \%$ and 5.6\%. Since mountains and hills are farther from the urban poles than the plains, this effect is probably driven by the unfavourable productive conditions, pushing farmers to seek more profitable marketing channels. However, the number of close commercial poles does not seem to be important. It is true that this variable is significant and positive for some TF (Mixed crops and Fieldcrops), but it bears a negative sign for Fruits and, in any case, the marginal effects are negligible. This suggests that transportation costs to the market are not a crucial variable in the choice to sell directly off the farm. Rather, the fact that the size of the population living at a short distance significantly and positively affects this choice (except for Sheep 
and Granivores) suggests that the opportunity to find interested consumers is more important. The magnitude of the effect is also sizeable: 1,000 more inhabitants at the 45 minutes distance increase the likelihood of off-farm direct sales by 0.5 to $6.8 \%$, according to the particular TF.

\subsection{The relationship between on-farm and off-farm direct sales}

In 2,014 farms over 58,304, i.e., $3.5 \%$ of the farms, direct sales are conducted both on and off the farm. This raises the question whether there is a connection between the uses of these two chains. We explored the issue in two ways. The first is estimating the choice of direct sales with a bivariate probit. It assumes that the error terms of the two equations are distributed as a bivariate normal, with a correlation coefficient $\rho$. We found a correlation coefficient of 0.41 , which is significant, thus suggesting that the two choices are correlated. However, the estimates of the parameters were sensibly similar to the ones found in the two separate estimates (the results are available upon request).

The second way was the estimation of an ordered probit. It assumes that there is a latent variable "propensity to direct sales" which is unobservable. One can only observe outcomes representing increasing discrete indicators of the latent variable, i.e., no direct sales, only one type (either on-farm or off-farm), or both, implying that the latent variable is comprised between specific thresholds. The model allows the estimation of the effects of the explanatory variables on the latent variable and of the thresholds (for identification reasons, a threshold must be assumed to be 0). The results are presented in Table 6, that also displays the marginal effects of the variables on the three outcomes. The results of the model are overall significant, and the threshold parameter is significant as well, thus implying that it actually discriminates between the different outcomes. The parameters bear the same signs and are very similar to the ones of the dummy models. Basically, the results of the ordered probit confirm that there is some relationship between on-farm and off-farm direct sales, and that the variables also have an effect on the cumulative decision of using both channels. However, it should be considered that the model implies that the explanatory variables affect in the same way the decision of engaging in on-farm direct sales only and the one to engage in off-farm sales only. 


\section{DisCUSSION AND CONCLUSIONS}

Some considerations can be drawn from the above results. The first one is that the distinction between on-farm and off-farm direct sales is relevant for the analysis of the determinants. In general, the data suggest that the effects of the explanatory variables are systematically stronger on the probability to sell directly on the farm rather than off the farm. In other words, the choice to sell off the farm is more driven by random effects and by idiosyncratic characteristics of the farm and of the farmer than the choice to sell on the farm. However, the two choices are not completely independent, since some unobservable characteristics affect both choices in the same way, as shown by the bivariate probit and by the ordered probit.

Personal characteristics of the operators do influence the choice, but definitely to a lesser extent relative to other variables. As found in other researches (Aguglia et al., 2009; Bonanno et al., 2014; Martinez et al., 2010), younger farmers are more interested in direct selling, though this is not true for all types of farming and a younger age seems more relevant for off-farm than for on-farm direct sales. Given that the former is less frequent, one could argue that it is more demanding also in terms of personal skills and open-minded attitude.

The type of farming is of great importance in determining the choice of the marketing channel. The type of products more conducive to direct sales can nevertheless be different according to the channel, on-farm and off-farm. For instance, horticulture is fitter for off-farm than for on-farm direct sales. There appears to exist an important complementarity between certain TFs and the type of direct sales. Though this cannot be detected by the statistical model we used, discussion with farmers and experts suggested that, at least for some farmers, the choice of the marketing channel is not only a matter of the distribution channel of the product, but often involves the overall setting of the farm. For instance, fruit-growers engaged in direct sales need to have different fruits and varieties, and horticulture producers have to grow a great variety of vegetables all along the year if they are to sell off the farm in urban markets. This is probably the main reason why mixed forms of farming are 
found to be the most conducive to direct sales. A further element to consider is that the type of farming also influences which other variables influence the choice. For example, male operators are more likely to engage in direct sales, both on- and off-farm when they grow grapes, while the opposite holds for horticulture. In addition, the effect of the type of farming may change according to the local conditions. For instance, the high share of wine farms engaged in direct sales that we found likely depends on Piedmont being a well renowned region for wine, and a destination of wine tourism.

Direct sales are often associated with diversification activities, a result holding also in the USA (Martinez et al., 2010). The stronger association is between agro-tourism and on-farm direct sales, a result largely obvious, but can be qualified by adding that this association is particularly tight in some TFs like Granivores (i.e., pigs and poultry; this TF nevertheless includes relatively few farms) and Horticulture. More surprising is the association of agro-tourism with off-farm direct sales, which holds for many TFs, as there is no evident direct link between agro-tourism and the choice to sell directly to consumers off the farm. We hypothesise that this is the result of an "advertising effect", in the sense that selling off the farm might give the opportunity to advertise the agro-touristic activity and vice versa and, possibly, of farmers' attitude to exploit alternative channels.

The effects of quality signals of the products is mixed. Organic farming favours direct sales on the farm, especially in some types of farming like horticulture and vineyards, and also off-farm direct sales, though to a lesser extent. By contrast, quality signals like PDO or PGI seem to have predominantly a negative effect. A possible explanation is that these are quality signals that can be better exploited in other marketing channels.

Farm location may affect both the demand and the supply side of direct sales. The farm being in hilly or mountainous areas makes direct sales more likely, both on-farm and off-farm. Lower yields and profitability in these areas can push farmers to explore alternative channels, in particular the possibility to sell to consumers on the farm and off the farm; but the vicinity to tourism areas is also a possible driver of the phenomenon, because tourists visiting these areas are more likely to buy on 
the farm. The consideration that the effects of location in hilly and mountainous areas are stronger for on-farm than for off-farm sales would suggest that the latter effect is dominant. Some similar considerations concern the geographical variables. Closeness to urban centres has already been shown to be favourable to direct sales (Bonanno et al., 2014; Martinez et al., 2010; Aguglia et al., 2009). However, closeness to commercial poles was not expected to be particularly affecting on-farm sales, which is actually true: the number of close commercial poles has in general a non-significant or negative effect on on-farm direct. By contrast, it was expected to positively affect off-farm sales, because of lower transportation costs from the farm to the outlet. The results suggest that this is only true to a minor degree. Rather, they show that the size of the population within short distance from the farm not only favours - as expected - on-farm sales, but also off-farm direct sales. This suggests that in the choice to engage in off-farm direct sales, considerations on the likely demand of the farm's products is more important than transportation costs. In addition, it is quite possible that in many cases the transportation costs are not much different from the ones in the conventional channels.

All these considerations help in drafting some policy considerations. Of course, policy goals are a matter of social and political decision-making. If enhancing consumer-producer relationships and building a social capital through these is an agreed policy goal, then favouring direct sales becomes a desirable goal too. However, the available tools to reach this goal appear as limited. The most effective variable in enhancing on-farm direct sales is agro-tourism and, hence, policies encouraging agro-tourism also favour on-farm direct sales and, to a lesser extent, off-farm direct sales. The other strong determinant is farm location but, obviously, this is not under the control of policy-makers. What is nevertheless possible in this respect is promoting structures for direct sales in the city centres available to farmers, so to reduce their distribution costs and to make it easier for them to reach the potential consumers. It might also be possible to create shops for the collective sale of farmers' products, so to share the relevant costs, though in this case the effect of the direct consumer-producer relationship would be reduced. Favouring organic production also indirectly favours direct sales, since they are more frequent in organic farms. Other traditional intervention tools influencing the 
farmers' human capital, like education and professional training, seem little effective according to our results. A last note concerns the environmental impacts of direct sales, if their reduction is included among the policy goals connected with direct sales. In general, the studies that analyse the energy intensity and resultant emissions of food distribution systems do not consider the retail-toconsumer link, because it is the least measurable and the most difficult to control (Wakeland et al., 2012). Nevertheless, some studies, such as those by Cholette and Venkat (2009) and Van Hauwermeiren et al. (2007), find that the most energy-intensive and $\mathrm{CO}_{2}$-emitting transit link is often the last one - driving to the store. A study by Mundler and Rumpus (2012) analyses the energy efficiency of different distribution systems, and find that the energy use is higher for on-farm sales than for off-farm sales (except for Collective Sales Points) because of consumer travel to the farm. Even though energy performance remains very dependent on where the study is conducted (Mundler and Rumpus, 2012), there is therefore some evidence that on-farm direct sales generally have a stronger environmental impact than off-farm direct sales for the same quantity of product, due to the emissions created by the sum of individual movement of consumers to buy on the farm. Hence, if these conjectures proved true and if environmental concerns are considered, off-farm direct sales should be encouraged ${ }^{10}$, rather than on-farm direct sales. This might be a problem, since in general we found that the explanatory variables affect off-farm direct sales to a limited extent, so that fewer levers are available to the policy-makers to favour them.

Some final considerations concern the limitations of our research. The main one is the lack of information on the subjective motivations of the participants in direct sales, since subjective motivations proved to be different among the participants to different types of Alternative Food Networks (e.g., Mastronardi et al., 2015). This is the cost to pay for using data concerning the totality of farmers. Nevertheless, our results indirectly confirm the importance of farmers' attitudes and

\footnotetext{
10 This is nevertheless conditional on proving that off-farm direct sales are more environmentally friendly than the conventional chain. Moreover, as suggested by one reviewer, if on-farm sales are linked to agro-tourism, a shift from onfarm to off-farm direct sales would not affect the environmental impact of visitors to agro-tourism facilities.
} 
preferences, to the extent that they might explain a part of the unexplained variation in our model, since observable personal characteristics do not appear to be much influential on farmers' choices. Second, a more fine-tuned examination of the different direct sales channels could be helpful. Due to our data availability, we distinguished the analysis between on-farm and off-farm direct sales, but there are more categories than these two: for instance, Santini and Gomez y Paloma (2013) list different varieties of on-farm sales, off-farm sales and farm direct deliveries. It is quite likely that the determinants of the engagement in different categories of direct sales differ. This is left to further research.

\section{ACKNOWLEDGMENT}

This research was funded by the University of Torino, Progetti di Ateneo [Call 3 "Strategic Research Grants", Project "Alternative Food Networks: an Interdisciplinary assessment"]. We wish to thank Regione Piemonte for allowing the use of Agricultural Census data and Lorena Cora of CSI-Piemonte for very helpful assistance in using the relevant data warehouse. We are also grateful to the anonymous referees and to the Editor for useful and helpful remarks on a previous version. Remaining errors are obviously ours.

\section{REFERENCES}

Aguglia L., De Santis F., Salvioni C. (2009), Direct Selling: a Marketing Strategy to Shorten Distances between Production and Consumption, Paper presented at the $113^{\text {th }}$ EAAE Seminar "A resilient European food industry and food chain in a challenging world", Chania, Crete, Greece, $\quad$ September 3 - 6, 2009, available at: http://ageconsearch.umn.edu/bitstream/57657/2/Aguglia.pdf

Adanacioglu H. (2016), Factors affecting farmers' decisions to participate in direct marketing: A case study of cherry growers in the Kemalpasa District of Izmir, Turkey. Renewable Agriculture and Food Systems, FirstView, available on CJO2016. doi:10.1017/S1742170516000193.

Aubert M. (2015). The determinants of selling through a short food supply chains: an application to the French case. 9. Journées de recherches en sciences sociales (JRSS), Dec. 2015, Nancy, France. Actes des journées JRSS 2015, 25 p.

Bonanno A., Pascucci S., Caracciolo F., Cembalo L. (2014), Farmers Participation in Short Channels in Italy: An Empirical Analysis, Poster paper prepared for presentation at the EAAE 2014 Congress 'Agri-Food and Rural Innovations for Healthier Societies' August 26 to 29, 2014 Ljubljana, Slovenia, available at: http://ageconsearch.umn.edu/bitstream/182968/2/EAAA_2014_Short_supply_chain_final.pdf 
Brown C., Miller, S. (2008). The Impacts of Local Markets: A Review of Research on Farmers Markets and Community Supported Agriculture (CSA). American Journal of Agricultural Economics, 90 (5): 1298-1302.

Cheng M., Bills N., Uva W-f.L. (2011). Farm-Direct Food Sales in the Northeast Region: A Country Level Analysis. Journal of Food Distribution Research, 42(1): 22-25.

Cholette S., Venkat. K. (2009). The energy and carbon intensity of wine distribution: A study of logistical options for delivering wine to consumers. Journal of Cleaner Production, 17(16): 1401-1413.

Corsi A., Borsotto P., Borri I., Strøm S. (2009). Diversification of the marketing chains among organic producers, Paper presented at the $27^{\text {th }}$ IAAE, Beijing, China, August 16-22, 2009, available at http://ageconsearch.umn.edu/bitstream/51422/2/Diversification\%20IAAE.pdf

Fafchamps M., Vargas Hill R. (2005). Selling at the Farmgate or Travelling to market. American Journal of agricultural Economics 87: 717-734.

Feenstra G.W. (1997), Local food systems and sustainable communities, American Journal of Alternative Agriculture, 12(1): 28-36

Feenstra, G.W., Lewis, C.C., Hinrichs, C.C., Gillespie Jr, G.W., Hilchey, D. (2003). Entrepreneurial outcomes and enterprise size in US retail farmers' markets. American Journal of Alternative Agriculture, 18(1): 46-55

Fletcher, S.M., Terza J.V. (1986). Analyzing Farmers' selection of Available Marketing Alternatives Using the Multivariate probit Model. Canadian Journal of Agricultural economics 34: 243-252.

Fu T., Epperson J.E., Terza J.V., Fletcher S.M. (1988). Producer Attitudes Toward Peanut Market Alternatives: An Application of Multivariate Probit Joint Estimation. American Journal of agricultural Economics 70: 910-918.

Gatrell J, Reid N., Ross P. (2011). Local Food Systems, Deserts, and Maps: the Spatial Dynamics and Policy Implications of Food Geography. Applied Geography, 1-2.

Herdesty S.D., Leff P. (2009). Determining marketing costs and returns in alternative marketing channels, Renewable Agriculture and Food Systems 25(1): 24-34

Ilbery B., Maye D., Kneafsey M., Jenkins T., Walkley C. (2004) Forecasting food supply chain developments in lagging rural regions: evidence from the UK, Journal of Rural Studies, 20: 331344

Istat (2016) Popolazione residente - Anno 2015, database available at: demo.istat.it

Jongeneel R.A., Polman N.B.P., Slangen L.H.G. (2008) Why are Dutch farmers going multifunctional? Land Use Policy 25(1): 81-94.

Lev L., Gwin L. (2010). Filling the Gaps: Eight Things to Recognize about Farm-Direct Marketing. Choices, 25(1)

Low S.A., Vogel S. (2011). Direct and Intermediated Marketing of Local Foods in the United States, ERR-128, U.S. Department of Agriculture, Economic Research Service, November 2011.

Lyson T.A., Gutpill A. (2004). Commodity Agriculture, Civic Agriculture and the Future of U.S. Farming. Rural Sociology 69(3): 370-385.

McLeay F., Zwart T. (1998). Factors Affecting Choice of Cash Sales Versus Forward Marketing Contracts. Agribusiness: an International Journal, 14: 299-309.

Martinez, S., M. Hand, M. Da Pra, S. Pollack, K. Ralston, T. Smith, S. Vogel, S. Clark, L. Lohr, S. Low, and C. Newman (eds.) (2010). Local food systems: concepts, impacts, and issues. Economic Research Report 97. Washington DC, US: USDA Economic Research Service 
Marsden T., Banks J., Bristow G. (2000). Food supply chain approaches: exploring their role in rural development. Sociologia Ruralis 4: 424-38.

Mastronardi L., Marino D., Cavallo A., Giannelli A. (2015), Exploring the Role of Farmers in Short Food Supply Chains: The Case of Italy, International Food and Agribusiness Management Review, 18 (2): 109-130

Monson J., Mainville D., Kuminoff N. (2008). The Decision to Direct Market: An Analysis of Small Fruit and Specialty-Product Markets in Virginia. Journal of Food Distribution Research, 39(2): $1-11$

Morgan K.T., Alipoe D. (2001). Factor Affecting the Number and Type of Small-Farm Direct Marketing Outlets in Mississippi. Journal of Food and Distribution Research, 32(1): 125- 132

Mundler, P., Rumpus, L. (2012). The energy efficiency of local food systems: A comparison between different modes of distribution, Food Policy, 37(6):609-615.

Murdoch J., Marsden T., Banks J. (2000). Quality, Nature, and Embeddedness: Some Theoretical Considerations in the Context of the Food Sector. Economic Geography 76: 107-125.

Santini F., Gomez y Paloma S. (eds.) (2013), Short Food Supply Chains and Local Food Systems in the EU. A State of Play of their Socio-Economic Characteristics, Luxembourg: Publications Office of the European Union

Sonnino R., Marsden T. (2006). Beyond the divide: rethinking relationships between alternative and conventional food networks in Europe. Journal of Economic Geography 6: 181-199.

Timmons D., Wang Q. (2010). Direct Food Sales in the United States: Evidence from State and County-Level Data. Journal of Sustainable Agriculture 34(2): 229-240.

Van Hauwermeiren A., Coene H., Engelen G., Mathijs E. (2007). Energy lifecycle inputs in food systems: A comparison of local versus mainstream cases. Journal of Environmental Policy \& Planning, 9(1): 31-51

Verhaegen I., Van Huylenbroeck G. (2001). Costs and benefits for farmers participating in innovative marketing channels for quality food products. Journal of Rural Studies 17: 443-456.

Wakeland W., Cholette S., Venkat K. (2012). Food transportation issues and reducing carbon footprint. In J.I. Boye and Y. Arcand (eds.), Green Technologies in Food Production and Processing, Food Engineering Series. Springer Science+Business Media, LLC 2012: 211-236

Whatmore, S., Stassart, P., Renting, H. (2003). What's alternative about alternative food networks? Environment and Planning 35: 389-391.

Winter, M. (2003). Embeddedness, the new food economy and defensive localism. Journal of Rural Studies 19: 23-32.

Wiskerke J. (2009), On Places Lost and Places Regained: Reflections on the Alternative Food Geography and Sustainable Regional Development, International Planning Studies, 14(4): 369387 
Table 1. Shares of farms practising direct sales by type of farming.

\begin{tabular}{|c|c|c|c|}
\hline \multirow{2}{*}{ Type of farming $(1242 / 2008(E C))$} & \multirow{2}{*}{ Number } & \multicolumn{2}{|c|}{ Direct market $(\%)$} \\
\hline & & on-farm & off-farm \\
\hline $\begin{array}{l}\text { Fieldcrops (specialist cereals - rice inclusive - and general f } \\
\text { cropping) }\end{array}$ & 18,220 & 5.0 & 3.5 \\
\hline Specialist horticulture & 1,544 & 13.2 & 16.1 \\
\hline Specialist vineyards & 11,938 & 24.3 & 13.6 \\
\hline $\begin{array}{l}\text { Other permanent crops (specialist fruit, olives and various } p \\
\text { crops combined) }\end{array}$ & 8,809 & 15.3 & 8.6 \\
\hline Specialist dairying & 2,228 & 13.5 & 5.6 \\
\hline Specialist cattle (rearing and fattening and dairying, rearing & & & \\
\hline fattening combined) & 5,363 & 7.5 & 2.7 \\
\hline Specialist sheep, goats and other grazing livestock & 2,087 & 14.1 & 4.7 \\
\hline Specialist granivores (pigs, poultry and various combined) & 927 & 8.3 & 4.4 \\
\hline Mixed types ${ }^{1}$ & 7,188 & 24.4 & 14.7 \\
\hline Total & 58,304 & 14.0 & 8.1 \\
\hline
\end{tabular}

Source: 2010 Agricultural Census, own elaboration

${ }^{1}$ Mixed cropping, mixed livestock, field crops and grazing livestock combined, various crops and livestock combined

Table 2. Descriptive statistics of the variables.

\begin{tabular}{|c|c|c|c|}
\hline Variables & Symbols & Mean & Std. Dev. \\
\hline On-farm direct sales $(0,1)$ & & 0.14 & 0.347 \\
\hline Off-farm direct sales $(0,1)$ & & 0.081 & 0.273 \\
\hline Operator's age (years) & AGE & 56.117 & 14.565 \\
\hline Operator's gender $(1=\mathrm{M})$ & GENDER & 0.723 & 0.447 \\
\hline Operator's schooling (years) & EDUC & 8.465 & 3.501 \\
\hline Op.'s agricultural school $(0,1)$ & AG_EDUC & 0.052 & 0.222 \\
\hline Op.'s professional training $(0,1)$ & PROF_TRAIN & 0.067 & 0.25 \\
\hline Plains $(0,1)$ & - & 0.366 & 0.482 \\
\hline Hills $(0,1)$ & HILLS & 0.506 & 0.5 \\
\hline Mountains $(0,1)$ & MOUNT & 0.128 & 0.334 \\
\hline Standard Output $(0,000 €)$ & ST_OUT & 62.708 & 22.022 \\
\hline Agro-tourism $(0,1)$ & AG_TOUR & 0.017 & 0.129 \\
\hline Recreational activities $(0,1)$ & RECREAT & 0.003 & 0.052 \\
\hline Organic farming $(0,1)$ & ORG & 0.034 & 0.18 \\
\hline PDO-PGI $(0,1)$ & PDO & 0.044 & 0.205 \\
\hline Fieldcrops $(0,1)$ & CEREALS & 0.313 & 0.464 \\
\hline Horticulture $(0,1)$ & HORTIC & 0.026 & 0.161 \\
\hline Vineyards $(0,1)$ & VINE & 0.205 & 0.404 \\
\hline Other permanent crops $(0,1)$ & FRUITS & 0.151 & 0.358 \\
\hline Dairying $(0,1)$ & DAIRY & 0.038 & 0.192 \\
\hline Cattle $(0,1)$ & BEEF & 0.092 & 0.289 \\
\hline Sheep and goats $(0,1)$ & SHEEPS & 0.036 & 0.186 \\
\hline Granivores $(0,1)$ & GRANIV & 0.016 & 0.125 \\
\hline Mixed & - & 0.123 & 0.329 \\
\hline \# commercial poles within $1 / 2 \mathrm{hr}$. drive & COMM_POL & 3.456 & 2.346 \\
\hline $\begin{array}{l}\text { Population living within } 45 \text { min. driving } \\
\text { distance }(000)\end{array}$ & POP_45 & 1100.63 & 780.218 \\
\hline
\end{tabular}

Source: 2010 Agricultural Census and 2011 Population Census, own elaboration 
Table 3. Results of the probit models of the determinants of direct sales (dummy model).

\begin{tabular}{|c|c|c|c|c|c|c|}
\hline & \multicolumn{3}{|c|}{ On-farm } & \multicolumn{3}{|c|}{ Off-farm } \\
\hline & Coeff. & $\begin{array}{l}\text { Std. } \\
\text { Err. }\end{array}$ & $\begin{array}{c}\text { Marginal } \\
\text { effect }\end{array}$ & Coeff. & Std. Err. & $\begin{array}{c}\text { Marginal } \\
\text { effect }\end{array}$ \\
\hline Constant & $-1.232 * * *$ & 0.056 & & $-1.403 * * *$ & 0.064 & -0.174 \\
\hline AGE & $-0.004 * * *$ & 0.001 & -0.001 & $-0.007 * * *$ & 0.001 & -0.001 \\
\hline GENDER & $0.045 * * *$ & 0.016 & 0.008 & $0.037 * *$ & 0.018 & 0.005 \\
\hline EDUC & $0.017 * * *$ & 0.002 & 0.003 & $0.008 * * *$ & 0.003 & 0.001 \\
\hline AG_EDUC & $0.196 * * *$ & 0.031 & 0.041 & $0.070 * *$ & 0.034 & 0.009 \\
\hline PROF_TRAIN & $0.228 * * *$ & 0.025 & 0.049 & $0.219 * * *$ & 0.028 & 0.031 \\
\hline HILLS & $0.457 * * *$ & 0.021 & 0.087 & $0.439 * * *$ & 0.024 & 0.055 \\
\hline MOUNT & $0.705 * * *$ & 0.029 & 0.178 & $0.370 * * *$ & 0.035 & 0.056 \\
\hline ST_OUT & $0.0007 * *$ & 0.000 & 0.000 & $0.001 * * *$ & 0.000 & 0.000 \\
\hline AG_TOUR & $0.884 * * *$ & 0.042 & 0.254 & $0.299 * * *$ & 0.049 & 0.046 \\
\hline RECREAT & $0.434 * * *$ & 0.110 & 0.105 & 0.202 & 0.128 & 0.029 \\
\hline ORG & $0.259 * * *$ & 0.034 & 0.057 & $0.354 * * *$ & 0.038 & 0.056 \\
\hline PDO & $-0.136 * * *$ & 0.037 & -0.024 & $-0.266 * * *$ & 0.047 & -0.027 \\
\hline CEREALS & $-0.791 * * *$ & 0.024 & -0.127 & $-0.650 * * *$ & 0.027 & -0.068 \\
\hline HORTIC & $-0.457 * * *$ & 0.045 & -0.066 & -0.030 & 0.043 & -0.004 \\
\hline VINES & -0.002 & 0.023 & 0.000 & $-0.044^{*}$ & 0.026 & -0.005 \\
\hline FRUITS & $-0.305 * * *$ & 0.024 & -0.051 & $-0.263 * * *$ & 0.027 & -0.028 \\
\hline DAIRY & $-0.369 * * *$ & 0.040 & -0.056 & $-0.450 * * *$ & 0.050 & -0.040 \\
\hline BEEF & $-0.708 * * *$ & 0.032 & -0.056 & $-0.839 * * *$ & 0.041 & -0.062 \\
\hline SHEEPS & $-0.552 * * *$ & 0.040 & -0.075 & $-0.630 * * *$ & 0.052 & -0.050 \\
\hline GRANIV & $-0.573 * * *$ & 0.072 & -0.076 & $-0.614 * * *$ & 0.087 & -0.048 \\
\hline COMM_POL & $-0.012 * * *$ & 0.004 & -0.002 & $0.030 * * *$ & 0.005 & 0.004 \\
\hline POP_45 & $0.142 * * *$ & 0.011 & 0.027 & $-1.403 * * *$ & 0.013 & 0.018 \\
\hline Log-likelihood & -20880.80 & & & -14903.90 & & \\
\hline Chi-squared & 5556.278 & & & 2970.192 & & \\
\hline d.f. & 22 & & & 22 & & \\
\hline N. Observations & 58304 & & & 58304 & & \\
\hline
\end{tabular}

$*, * *, * * *=$ significant at the $1 \%, 5 \%, 10 \%$, respectively 
Table 4. Estimates of the probit models of the determinants of on-farm direct sales (split model).

\begin{tabular}{|c|c|c|c|c|c|c|c|c|c|c|c|c|c|c|c|}
\hline \multirow[b]{3}{*}{ Constant } & \multicolumn{3}{|c|}{ Mixed crops } & \multicolumn{3}{|c|}{ Fieldcrops } & \multicolumn{3}{|c|}{ Horticulture } & \multicolumn{3}{|c|}{ Vineyards } & \multicolumn{3}{|c|}{ Fruits } \\
\hline & Coeff. & Std.Err. & Marg. Eff. & Coeff. & Std.Err. & Marg. Eff. & Coeff. & Std.Err. & Marg. Eff. & Coeff. & Std.Err. & Marg. Eff. & Coeff. & Std.Err. & $\begin{array}{l}\text { Marg. } \\
\text { Eff. }\end{array}$ \\
\hline & $-1.255^{* * *}$ & 0.132 & & $-1.423 * * *$ & 0.123 & & $-0.777 * *$ & 0.322 & & $-1.906 * * *$ & 0.120 & & $-1.415^{* * *} *$ & 0.131 & \\
\hline AGE & $-0.005 * * *$ & 0.001 & $-0.001 * * *$ & $-0.010 * * *$ & 0.001 & $-0.001 * * *$ & -0.004 & 0.004 & -0.001 & -0.001 & 0.001 & 0.000 & -0.002 & 0.001 & 0.000 \\
\hline GENDER & 0.029 & 0.037 & 0.009 & $-0.101 * * *$ & 0.036 & $-0.009 * * *$ & $-0.156^{*}$ & 0.093 & -0.033 & $0.200 * * *$ & 0.031 & $0.059 * * *$ & $0.062 *$ & 0.036 & $0.014^{*}$ \\
\hline EDUC & $0.031 * * *$ & 0.006 & $0.009 * * *$ & 0.000 & 0.006 & 0.000 & -0.017 & 0.015 & -0.003 & $0.011 * * *$ & 0.004 & $0.003 * * *$ & $0.028 * * *$ & 0.006 & $0.006 * * *$ \\
\hline AG_EDUC & 0.124 & 0.078 & 0.039 & $0.144 * *$ & 0.073 & $0.013^{*}$ & $-0.365 * *$ & 0.159 & $-0.063 * * *$ & $0.519 * * *$ & 0.056 & $0.181 * * *$ & 0.053 & 0.083 & 0.012 \\
\hline PROF_TRAIN & $0.325 * * *$ & 0.062 & $0.108 * * *$ & $0.201 * * *$ & 0.068 & $0.019 * *$ & 0.046 & 0.132 & 0.010 & 0.060 & 0.047 & 0.019 & $0.294 * * *$ & 0.067 & $0.076 * * *$ \\
\hline HILLS & $0.522 * * *$ & 0.046 & $0.156 * * *$ & $0.607 * * *$ & 0.041 & $0.064 * * *$ & -0.051 & 0.100 & -0.010 & $0.503 * * *$ & 0.069 & $0.127 * * *$ & $0.080 *$ & 0.048 & $0.018^{*}$ \\
\hline MOUNT & $0.734 * * *$ & 0.064 & $0.254 * * *$ & $0.927 * * *$ & 0.062 & $0.147 * * *$ & 0.042 & 0.160 & 0.009 & $0.476 * * *$ & 0.128 & $0.166^{* * *}$ & $0.193 * * *$ & 0.065 & $0.046^{* * *}$ \\
\hline ST_OUT & -0.004 & 0.000 & -0.001 & 0.001 & 0.002 & 0.000 & 0.000 & 0.000 & 0.000 & $0.011 * * *$ & 0.000 & $0.003 * * *$ & 0.000 & 0.003 & 0.000 \\
\hline AG_TOUR & $0.754 * * *$ & 0.091 & $0.273 * * *$ & $0.931 * * *$ & 0.120 & $0.160 * * *$ & $1.136^{* * *}$ & 0.253 & $0.364 * * *$ & $0.770 * * *$ & 0.077 & $0.281 * * *$ & $0.998 * * *$ & 0.124 & $0.328 * * *$ \\
\hline RECREAT & $0.598^{* *}$ & 0.241 & $0.213^{* *}$ & $0.798 * * *$ & 0.288 & $0.126^{*}$ & $1.387 * *$ & 0.625 & $0.466^{*}$ & 0.231 & 0.365 & 0.076 & 0.545 & 0.411 & 0.158 \\
\hline ORG & $0.328 * * *$ & 0.066 & $0.109 * * *$ & $0.542 * * *$ & 0.097 & $0.070 * * *$ & $0.739 * * *$ & 0.227 & $0.212 * * *$ & $0.641 * * *$ & 0.100 & $0.231 * * *$ & -0.051 & 0.064 & -0.011 \\
\hline COMM_POL & -0.007 & 0.009 & -0.002 & 0.002 & 0.008 & 0.000 & -0.024 & 0.000 & -0.005 & $0.037 * * *$ & 0.012 & $0.011 * * *$ & $-0.056^{* * *}$ & 0.012 & $-0.013 * * *$ \\
\hline POP_45 & $0.061 * * *$ & 0.027 & $0.019 * *$ & 0.033 & 0.024 & 0.003 & $0.154^{* *}$ & 0.065 & $0.031 * *$ & $0.381 * * *$ & 0.028 & $0.116^{* * *}$ & $0.326 * * *$ & 0.030 & $0.074 * * *$ \\
\hline Log-likelihood & -3689.573 & & & -3263.37 & & & -573.06 & & & -6187.85 & & & -3599.06 & & \\
\hline Chi squared & 611.38 & & & 718.923 & & & 59.461 & & & 859.46 & & & 337.570 & & \\
\hline df & 14 & & & 14 & & & 13 & & & 14 & & & 14 & & \\
\hline Obs. & 7188 & & & 18220 & & & 1544 & & & 11938 & & & 8809 & & \\
\hline
\end{tabular}

$*, * *, * * *=$ significant at the $1 \%, 5 \%, 10 \%$, respectively

Explanatory variables with insufficient variation within the TF were excluded from the estimation 
Table 4 (cnd). Estimates of the probit models of the determinants of on-farm direct sales (split model).

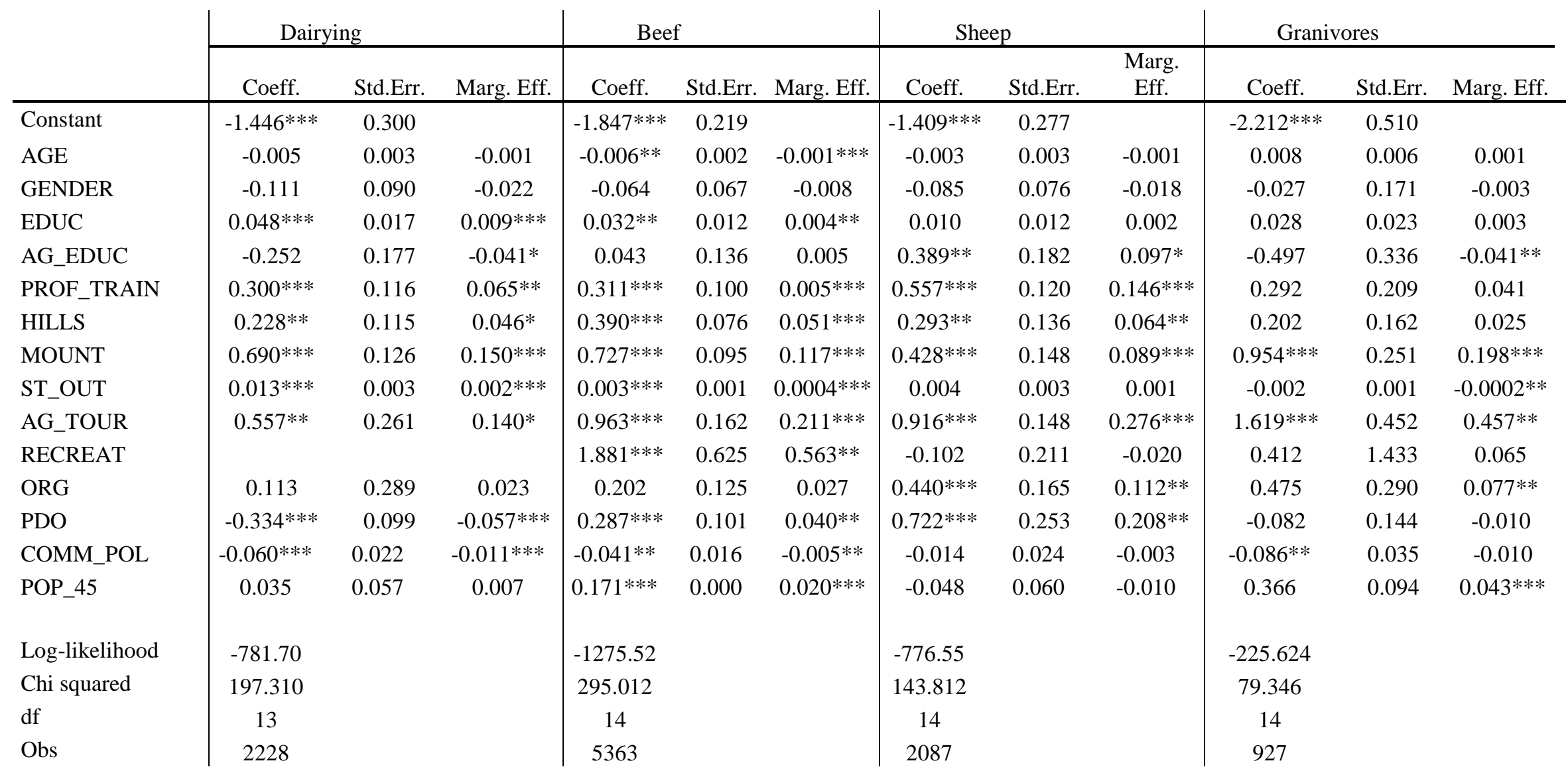

$*, * *, * * *=$ significant at the $1 \%, 5 \%, 10 \%$, respectively

Explanatory variables with insufficient variation within the TF were excluded from the estimation 
Table 5. Estimates of the probit models of the determinants of off-farm direct sales (split model).

\begin{tabular}{|c|c|c|c|c|c|c|c|c|c|c|c|c|c|c|c|}
\hline & \multicolumn{3}{|c|}{ Mixed crops } & \multicolumn{3}{|c|}{ Fieldcrops } & \multicolumn{3}{|c|}{ Horticulture } & \multicolumn{3}{|c|}{ Vineyards } & \multicolumn{3}{|c|}{ Fruits } \\
\hline & Coeff. & Std.Err. & Marg. Eff. & Coeff. & Std.Err. & Marg. Eff. & Coeff. & Std.Err. & Marg. Eff. & Coeff. & Std.Err. & Marg. Eff. & Coeff. & Std.Err. & Marg. Eff \\
\hline Constant & $-1.370 * * *$ & 0.145 & & $-1.714 * * *$ & 0.136 & & $-0.577^{*}$ & 0.311 & & $-1.674 * * *$ & 0.137 & & $-1.562 * * *$ & 0.155 & \\
\hline AGE & $-0.009 * * *$ & 0.002 & $-0.002 * * *$ & $-0.011 * * *$ & 0.001 & $-0.001 * * *$ & -0.005 & 0.004 & -0.001 & $-0.006 * * *$ & 0.001 & $-0.001 * * *$ & $-0.004 * *$ & 0.002 & $-0.001 * *$ \\
\hline GENDER & -0.022 & 0.042 & -0.005 & $-0.110 * * *$ & 0.040 & $-0.007 * * *$ & $-0.334 * * *$ & 0.089 & $-0.080 * * *$ & $0.237 * * *$ & 0.036 & $0.046 * * *$ & 0.022 & 0.043 & -0.001 \\
\hline EDUC & $0.016 * *$ & 0.007 & $0.004 * *$ & -0.005 & 0.006 & 0.000 & $-0.052 * * *$ & 0.015 & $-0.011 * * *$ & $0.011 * *$ & 0.005 & $0.002 * * *$ & 0.000 & 0.007 & 0.000 \\
\hline AG_EDUC & -0.021 & 0.085 & -0.005 & 0.093 & 0.082 & 0.006 & $-0.548 * * *$ & 0.171 & $-0.096 * * *$ & $0.197 * * *$ & 0.060 & $0.045 * * *$ & 0.073 & 0.096 & 0.011 \\
\hline PROF_TRAIN & $0.257 * * *$ & 0.067 & $0.063 * * *$ & $0.156^{* *}$ & 0.076 & $0.011^{*}$ & 0.030 & 0.132 & 0.007 & $0.215^{* * *}$ & 0.049 & $0.049 * * *$ & $0.217 * * *$ & 0.076 & $0.036 * *$ \\
\hline HILLS & $0.480 * * *$ & 0.049 & $0.103 * * *$ & $0.583 * * *$ & 0.044 & $0.048 * * *$ & $0.235 * *$ & 0.094 & $0.052 * *$ & $0.319 * * *$ & 0.081 & $0.056 * * *$ & $0.205 * * *$ & 0.057 & $0.029 * * *$ \\
\hline MOUNT & $0.271 * * *$ & 0.074 & $0.065 * * *$ & $0.598 * * *$ & 0.077 & $0.062 * * *$ & -0.137 & 0.178 & -0.029 & $0.327 * *$ & 0.148 & $0.080 *$ & 0.045 & 0.081 & 0.007 \\
\hline ST_OUT & 0.000 & 0.000 & -0.001 & 0.001 & 0.000 & 0.000 & 0.000 & 0.000 & -0.001 & $0.098 * * *$ & 0.000 & $0.002 * * *$ & $0.009 * * *$ & 0.000 & $0.001 * * *$ \\
\hline AG_TOUR & -0.165 & 0.107 & $-0.033 *$ & $0.318 * *$ & 0.153 & 0.027 & -0.044 & 0.304 & -0.009 & $0.345 * * *$ & 0.081 & $0.085^{* * *}$ & $0.424 * * *$ & 0.142 & $0.082 * *$ \\
\hline RECREAT & $0.413 *$ & 0.233 & 0.110 & $0.760 * *$ & 0.307 & 0.097 & $1.147^{*}$ & 0.598 & 0.385 & 0.347 & 0.376 & 0.086 & 0.002 & 0.471 & 0.000 \\
\hline ORG & $0.393 * * *$ & 0.073 & $0.102 * * *$ & $0.562 * * *$ & 0.108 & $0.060 * * *$ & $0.616 * * *$ & 0.240 & $0.178 * *$ & $0.607 * * *$ & 0.101 & $0.168 * * *$ & $0.161 * *$ & 0.074 & $0.026 * *$ \\
\hline PDO & $-0.437 * * *$ & 0.138 & $-0.074 * * *$ & $0.487 * *$ & 0.201 & $0.049 *$ & & & & -0.087 & 0.100 & -0.017 & $-0.351 * * *$ & 0.097 & $-0.041 * *$ \\
\hline COMM_POL & $0.059 * * *$ & 0.010 & $0.013 * * *$ & $0.050 * * *$ & 0.008 & $0.003 * * *$ & 0.002 & 0.017 & 0.000 & 0.017 & 0.014 & 0.004 & $-0.031 * *$ & 0.014 & $-0.005 * *$ \\
\hline POP_45 & $0.115^{* * *}$ & 0.000 & $0.025 * * *$ & $0.081 * * *$ & 0.000 & $0.005 * * *$ & $0.310 * * *$ & 0.000 & $0.068 * * *$ & $0.175 * * *$ & 0.000 & $0.036 * * *$ & $0.333 * * *$ & 0.000 & $0.049 * * *$ \\
\hline Log-likelihood & -2842.561 & & & -2564.1 & & & & & & -4519.31 & & & -2474.67 & & \\
\hline Chi squared & 328.241 & & & 342.441 & & & -626.244 & & & 438.410 & & & 203.803 & & \\
\hline df & 14 & & & 14 & & & 111.70 & & & 14 & & & 14 & & \\
\hline Obs & 7188 & & & 18220 & & & 1544 & & & 11938 & & & 8809 & & \\
\hline
\end{tabular}


Table 5 (cnd.). Estimates of the probit models of the determinants of off-farm direct sales (split model).

\begin{tabular}{|c|c|c|c|c|c|c|c|c|c|c|c|c|}
\hline & \multicolumn{3}{|c|}{ Dairying } & \multicolumn{3}{|c|}{ Beef } & \multicolumn{3}{|c|}{ Sheep } & \multicolumn{3}{|c|}{ Granivores } \\
\hline & Coeff. & Std.Err. & Marg. Eff. & Coeff. & Std.Err. & Marg. Eff. & Coeff. & Std.Err. & Marg. Eff. & Coeff. & Std.Err. & Marg. Eff. \\
\hline Constant & $-2.450 * * *$ & 0.385 & & $-2.375^{* * *}$ & 0.297 & & $-2.123^{* * *}$ & 0.373 & & $-1.591 * * *$ & 0.569 & \\
\hline AGE & $-0.007 *$ & 0.004 & $-0.001 *$ & -0.003 & 0.003 & 0.000 & -0.003 & 0.004 & -0.000 & $-0.015^{* *}$ & 0.008 & $-0.001 * *$ \\
\hline GENDER & -0.022 & 0.121 & -0.002 & 0.031 & 0.096 & 0.002 & -0.001 & 0.105 & 0.000 & -0.132 & 0.200 & -0.009 \\
\hline EDUC & $0.053 * *$ & 0.021 & $0.005^{* *}$ & 0.017 & 0.017 & 0.001 & 0.025 & 0.016 & 0.002 & $0.065^{* *}$ & 0.026 & $0.004 * *$ \\
\hline AG_EDUC & $-0.457 * *$ & 0.223 & $-0.030 * * *$ & 0.240 & 0.168 & 0.016 & $0.430 * *$ & 0.213 & 0.053 & -0.414 & 0.333 & $-0.018^{*}$ \\
\hline HILLS & $0.348 * *$ & 0.142 & $0.038^{* *}$ & $0.247 * *$ & 0.099 & $0.015^{* *}$ & 0.289 & 0.184 & 0.028 & $0.422 * *$ & 0.199 & $0.031 *$ \\
\hline MOUNT & $0.796 * * *$ & 0.165 & $0.098 * * *$ & $0.449 * * *$ & 0.126 & $0.032 * * *$ & 0.298 & 0.200 & 0.026 & $0.534 *$ & 0.310 & 0.050 \\
\hline ST_OUT & $0.012 * * *$ & 0.000 & $0.001 * * *$ & $0.002 *$ & 0.000 & $0.000 *$ & 0.000 & 0.000 & 0.000 & -0.001 & 0.000 & 0.000 \\
\hline AG_TOUR & 0.393 & 0.318 & 0.050 & $0.820 * * *$ & 0.192 & $0.095^{* *}$ & $0.395 * *$ & 0.197 & 0.047 & -0.171 & 0.582 & -0.009 \\
\hline RECREAT & & & & 0.384 & 0.646 & 0.031 & -0.421 & 0.348 & $-0.026^{*}$ & & & \\
\hline ORG & 0.253 & 0.346 & 0.029 & 0.111 & 0.180 & 0.007 & $0.626 * * *$ & 0.194 & $0.088 * *$ & $0.585^{*}$ & 0.326 & 0.059 \\
\hline PDO & $-0.302 * *$ & 0.124 & $-0.025^{* * *}$ & -0.057 & 0.160 & -0.003 & -0.210 & 0.388 & -0.015 & $-0.539 * * *$ & 0.193 & $-0.034 * * *$ \\
\hline COMM_POL & 0.016 & 0.026 & 0.001 & 0.006 & 0.021 & 0.000 & 0.023 & 0.033 & 0.002 & 0.016 & 0.046 & 0.001 \\
\hline POP_45 & $0.208 * * *$ & 0.000 & $0.019 * * *$ & $0.106^{*}$ & 0.000 & $0.006^{*}$ & -0.091 & 0.000 & -0.079 & 0.044 & 0.000 & 0.003 \\
\hline Log-likelihood & -444.3974 & & & -628.113 & & & -375.015 & & & -143.216 & & \\
\hline Chi squared & 74.19 & & & 62.516 & & & 46.773 & & & 49.43 & & \\
\hline df & 13 & & & 14 & & & 14 & & & 13 & & \\
\hline Obs & 2228 & & & 5363 & & & 2087 & & & 927 & & \\
\hline
\end{tabular}

$*, * *, * * *=$ significant at the $1 \%, 5 \%, 10 \%$, respectively

Explanatory variables with insufficient variation within the TF were excluded from the estimation 
Table 6. Results of the ordered probit model of the determinants of direct sales

\begin{tabular}{|c|c|c|c|c|c|}
\hline \multirow[b]{3}{*}{ Constant } & \multirow[b]{2}{*}{ Coeff. } & \multirow[b]{2}{*}{ Std.Err. } & \multicolumn{3}{|c|}{ Marginal effects on: } \\
\hline & & & No direct sales & On- or off-farm & On- and off-farm \\
\hline & $-0.961 * * *$ & 0.050 & & & \\
\hline AGE & $-0.006 * * *$ & 0.001 & 0.001 & -0.001 & 0.000 \\
\hline GENDER & $0.043 * * *$ & 0.014 & -0.010 & 0.008 & 0.002 \\
\hline EDUC & $0.014 * * *$ & 0.002 & -0.003 & 0.003 & 0.001 \\
\hline AG_EDUC & $0.152 * * *$ & 0.028 & -0.039 & 0.031 & 0.009 \\
\hline PROF_TRAIN & $0.241 * * *$ & 0.023 & -0.064 & 0.050 & 0.015 \\
\hline HILLS & $0.500 * * *$ & 0.018 & -0.120 & 0.095 & 0.025 \\
\hline MOUNT & $0.658 * * *$ & 0.026 & -0.195 & 0.142 & 0.053 \\
\hline ST_OUT & $0.001 * * *$ & 0.000 & 0.000 & 0.000 & 0.000 \\
\hline AG_TOUR & $0.702 * * *$ & 0.038 & -0.221 & 0.154 & 0.067 \\
\hline RECREAT & $0.358 * * *$ & 0.099 & -0.101 & 0.076 & 0.025 \\
\hline ORG & $0.310 * * *$ & 0.030 & -0.085 & 0.065 & 0.020 \\
\hline PDO & $-0.210 * * *$ & 0.034 & 0.046 & -0.037 & -0.008 \\
\hline CEREALS & $-0.811 * * *$ & 0.021 & 0.167 & -0.135 & -0.031 \\
\hline HORTIC & $-0.269 * * *$ & 0.037 & 0.056 & -0.046 & -0.010 \\
\hline VINE & -0.030 & 0.020 & 0.007 & -0.006 & -0.001 \\
\hline FRUITS & $-0.319 * * *$ & 0.021 & 0.068 & -0.056 & -0.012 \\
\hline DAIRY & $-0.444 * * *$ & 0.036 & 0.085 & -0.071 & -0.014 \\
\hline BEEF & $-0.834 * * *$ & 0.029 & 0.137 & -0.116 & -0.022 \\
\hline SHEEPS & $-0.644 * * *$ & 0.037 & 0.111 & -0.093 & -0.017 \\
\hline GRANIV & $-0.635^{* * *}$ & 0.064 & 0.108 & -0.091 & -0.017 \\
\hline COMM_POL & $0.007 *$ & 0.004 & -0.002 & 0.001 & 0.000 \\
\hline POP_45 & $0.157 * * *$ & 0.000 & 0.000 & 0.000 & 0.000 \\
\hline Threshold 1 & $1.045^{* * *}$ & 0.010 & & & \\
\hline Log-likelihood & $-29,892.04$ & & & & \\
\hline Chi-squared (22 d.f.) & $6,810.02$ & & & & \\
\hline N. Observations & 58,304 & & & & \\
\hline
\end{tabular}

